\title{
Parathyroid hormone reference ranges in healthy individuals classified by vitamin $D$ status
}

\author{
N. Yalla ${ }^{1} \cdot$ G. Bobba ${ }^{2} \cdot$ G. Guo ${ }^{3} \cdot$ A. Stankiewicz ${ }^{3} \cdot$ R. Ostlund ${ }^{1}$
}

Received: 20 December 2018 / Accepted: 11 June 2019 / Published online: 4 July 2019

(c) The Author(s) 2019

\begin{abstract}
Purpose Parathyroid hormone (PTH) concentrations are routinely measured in the diagnosis and management of bone and kidney diseases, but reference ranges can be overestimated if determined in otherwise healthy individuals for whom vitamin $\mathrm{D}$ deficiency was not evaluated. We establish PTH reference ranges in apparently healthy, normocalcemic, normophosphatemic individuals categorized by 25 -hydroxyvitamin D $(25(\mathrm{OH}) \mathrm{D})$ status using the Elecsys ${ }^{\circledR}$ PTH (cobas e 601) and Elecsys ${ }^{\circledR}$ Vitamin D total II electrochemiluminescence immunoassays (cobas e 411).

Methods This prospective, non-interventional study measured PTH in serum from 653 apparently healthy adults [56.7\% female; 68.2\% white/Caucasian; 28.6\% African American; median age 44 years (range 21-83)] from three diverse geographic sites across the USA during summer and winter months. Subjects were classified by concomitant vitamin D sufficiency $(\geq 30 \mathrm{ng} / \mathrm{mL})$, insufficiency ( $>20$ to $<30 \mathrm{ng} / \mathrm{mL})$ or deficiency $(\leq 20 \mathrm{ng} / \mathrm{mL})$.

Results In vitamin D sufficiency, median PTH was $31.9 \mathrm{pg} / \mathrm{mL}$ [range (2.5th-97.5th percentile) 17.9-58.6] compared with $35.5 \mathrm{pg} / \mathrm{mL}$ (17.0-60.4) for insufficiency, and $39.8 \mathrm{pg} / \mathrm{mL}$ (19.5-86.4) for deficiency. A significant inverse relationship was found between PTH and $25(\mathrm{OH}) \mathrm{D}(P<0.001)$. After accounting for vitamin $\mathrm{D}$, potential effects of race or season as covariates were relatively small or absent.

Conclusions Upper reference limits (URL) for PTH in vitamin D sufficiency/insufficiency were similar and lower than current values. Clinically important PTH elevations were observed in vitamin D deficiency, where revised reference ranges with a higher URL may be appropriate. These data may help to distinguish vitamin D-related PTH elevations from other causes [e.g., primary (normocalcemic) or secondary hyperparathyroidism].
\end{abstract}

Keywords Parathyroid hormone $\cdot$ Vitamin D · 25-Hydroxyvitamin D (25(OH)D) · Reference range

\section{Introduction}

Parathyroid hormone (PTH) and vitamin D are major regulators of mineral metabolism and form a tightly controlled feedback cycle; PTH stimulates 1,25-dihydroxyvitamin D synthesis, which in turn exerts a negative feedback on the parathyroid glands [1, 2]. PTH concentrations are routinely measured in the diagnosis and management of bone and mineral disease and chronic kidney disease (CKD) [3, 4]; however, the target range for PTH may vary significantly

R. Ostlund

rostlund@wustl.edu

1 Washington University, St. Louis, MO, USA

2 Roche Diagnostics International Ltd, Rotkreuz, Switzerland

3 Roche Diagnostics Inc., Indianapolis, IN, USA depending on vitamin $\mathrm{D}$ status, defined as the sum of $25(\mathrm{OH}) \mathrm{D}_{2}$ and $25(\mathrm{OH}) \mathrm{D}_{3}$ circulating levels $[5,6]$. Vitamin $\mathrm{D}$ deficiency occurs frequently in the general population, with an estimated prevalence of $41.6 \%$ among US adults, increasing to $82.1 \%$ in black individuals, and elevated PTH secretion is associated with vitamin D deficiency $[1,2,7]$. Given the interdependency of PTH and vitamin D, reference ranges for PTH may be overestimated if determined in a population of otherwise healthy individuals for whom vitamin D deficiency was not evaluated. Accurate reference ranges for PTH may facilitate more reliable diagnosis and management of conditions such as primary hyperparathyroidism and end-stage renal disease [8-11].

We aimed to determine accurate reference ranges for PTH by vitamin $D$ status in apparently healthy individuals. Serum 25(OH)D (sum of $\mathrm{D}_{2}$ and $\mathrm{D}_{3}$ ) and intact PTH were measured using the Elecsys ${ }^{\circledR}$ Vitamin D total II and Elecsys ${ }^{\circledR}$ PTH 
electrochemiluminescence assays, respectively (Roche Diagnostics GmbH, Mannheim, Germany) [12, 13].

\section{Methods}

\section{Study design and participants}

We conducted a multicenter, prospective, non-interventional study to determine reference ranges for intact PTH in apparently healthy, normocalcemic, normophosphatemic individuals according to vitamin D status, using the Elecsys ${ }^{\circledR}$ PTH and Elecsys ${ }^{\circledR}$ Vitamin D total II electrochemiluminescence immunoassays. Volunteers were enrolled at three geographic sites across the USA (Century Clinical Research Inc., Daytona Beach, Florida, USA; NB Research, Indianapolis, Indiana, USA; Prism Research, LLC., St Paul, Minnesota, USA). Prior to study initiation, ethical approval was obtained from relevant institutional review boards. The study was conducted in accordance with the principles of the Declaration of Helsinki and International Conference on Harmonisation guidelines for Good Clinical Practice; all participants provided written informed consent.

Apparently, healthy individuals aged $\geq 21$ years with body mass index (BMI) $18-30 \mathrm{~kg} / \mathrm{m}^{2}$ were enrolled. Key inclusion criteria were: calcium ( $\leq 60$ years, $8.6-10.0 \mathrm{mg}$ / $\mathrm{dL}$; $>60$ years, $8.8-10.2 \mathrm{mg} / \mathrm{dL})$, phosphate $(2.5-4.5 \mathrm{mg} /$ $\mathrm{dL}$ ), and creatinine (female $0.51-0.95 \mathrm{mg} / \mathrm{dL}$; male $0.67-1.17 \mathrm{mg} / \mathrm{dL}$ ), based on medical history and confirmatory testing; geographic location within $\pm 2^{\circ}$ latitude or 138 miles north/south of collection site for $\geq 4$ weeks. Key exclusion criteria were pregnancy (self-declared/ $\leq 12$ months); breastfeeding or lactation ( $\leq 3$ months); endocrine/metabolic disease known to affect vitamin D metabolism or interfering with bone metabolism; abnormal calcium, including hypocalcemia, hypocalciuria, hypophosphatemia, or hypercalcemia caused by primary hyperparathyroidism, vitamin D overdose/intoxication, or cancer; bariatric surgery; vigorous exercise ( $>2 \mathrm{~h}$ /day); hospitalization/immobilization $>7$ days ( $\leq 3$ months); bone fracture ( $\leq 3$ months). Individuals taking the following supplements or drugs influencing bone and calcium/phosphorus metabolism were excluded: PTH analogs and/or modified PTH compound; other anabolic medication; anticonvulsants; antiresorptive drugs, e.g., bisphosphonates, calcitonin; hormone replacement therapy; calcium carbonate; diuretics; fluoride; glucocorticoids; highdose vitamin D supplements (>1000 IU/day).

\section{Sample collection and storage}

Blood samples were collected during summer (August 2015 and June 2016) and winter months (December 2015 and February 2016); an individual could only contribute an evaluable sample during one collection period. Aliquots of serum samples were prepared within $2 \mathrm{~h}$ of venipuncture and immediately frozen for storage at $-70{ }^{\circ} \mathrm{C}$ or colder. De-identified samples were tested at a central laboratory (Washington University, USA).

\section{Determination of PTH reference ranges}

Serum PTH and 25(OH)D concentrations were measured with the Elecsys ${ }^{\circledR}$ PTH and Elecsys ${ }^{\circledR}$ Vitamin D total II electrochemiluminescence immunoassays on the cobas $\mathbf{e}$ 601 and cobas e 411 analyzers, respectively. The Elecsys ${ }^{\circledR}$ PTH assay employs the sandwich test principle, whereas the Elecsys ${ }^{\circledR}$ Vitamin D total II assay employs a competition principle. Both assays have turnaround times of less than 30 min. The Elecsys ${ }^{\circledR}$ Vitamin D total II assay has been standardized using internal standards, which are traceable to the ID-LC-MS/MS 25-hydroxyvitamin D Reference Measurement Procedure [14, 15]. The ID-LC-MS/ MS is traceable to the National Institute of Standards and Technology Standard Reference Materials 2972 [16]. The Elecsys ${ }^{\circledR}$ PTH assay was standardized against a commercial PTH test (RIA) [13]. Recovery of the NIBSC 95/646 (WHO) standard was assessed using serial dilutions in human serum covering the measuring range $(40-4000 \mathrm{pg} /$ $\mathrm{mL}$ ) on multiple analyzers, and resulted in a mean recovery of $100 \% \pm 4 \%$. Calcium, phosphate and creatinine concentrations were measured with the Calcium Gen 2, Phosphate Inorganic version 2 and Creatinine Plus version 2 assays (respectively; Roche Diagnostics GmbH, Mannheim, Germany), on the cobas c 501 analyzer. Assays were performed according to manufacturer instructions with daily QC runs.

Target sample size was 190 evaluable individuals per site (minimum $n=146$ ). PTH reference ranges [medians 2.5th-97.5th percentiles and 95\% confidence intervals (CI) of the upper (URL) and lower reference limits (LRL)] were calculated using standard nonparametric analyses, according to CLSI EP28-A3c guidelines [17]. PTH reference ranges were determined for three cohorts by vitamin D status: deficiency $(25(\mathrm{OH}) \mathrm{D} \leq 20 \mathrm{ng} / \mathrm{mL})$, insufficiency $(25(\mathrm{OH}) \mathrm{D}>20$ to $<30 \mathrm{ng} / \mathrm{mL})$, and sufficiency $(25(\mathrm{OH}) \mathrm{D}$ $\geq 30 \mathrm{ng} / \mathrm{mL}$ ), per national guidelines [18, 19].

\section{Statistical analyses}

Bivariate associations were evaluated using both Pearson's correlation $(R)$ and Kendall's Tau. Kruskal-Wallis analysis was used as a non-parametric approach to assess the statistical significance of differences in serum PTH measurements by $25(\mathrm{OH}) \mathrm{D}$ categories and by demographic 
variables, including race and site. When overall differences were found, the significance of pairwise comparisons was determined using the Dwass-Steel-Critchlow-Fligner (DSCF) multiple comparison procedure. General linear regression modeling was used to assess the association between PTH and 25(OH)D measurements in serum. Natural log transformations were performed on serum PTH measurements to normalize the distribution and reduce the influence of outliers when calculating Pearson's $R$ and analyzing general linear regression models. Covariates of race, site, or season were added to the general linear regression model of $\mathrm{PTH}=25(\mathrm{OH}) \mathrm{D}$ to assess their impact on PTH in serum.

\section{Results}

\section{Analysis population}

Samples were collected from 653 individuals; 490 evaluable serum samples were included in the analyses (Fig. 1). A total of 163 individuals were excluded prior to analyses; the most frequent reason for exclusion was creatinine level outside the accepted range during exclusionary testing $(n=84)$. In the evaluable cohort, median (range) age was 44 (21-83) years and 278 (56.7\%) individuals were female; 334 (68.2\%) were white/Caucasian, 140 (28.6\%) were black/African American, and 5 (1.0\%) were Asian.
Across all samples, median (2.5th-97.5th percentile) serum PTH concentration was $35.5 \mathrm{pg} / \mathrm{mL}$ [17.3 (95\% CI 13.8-19.5) to 76.4 (95\% CI 68.8-90.9) pg/mL]. Median PTH concentrations and associated URLs decreased with increasing 25(OH)D concentration (Table 1); among vitamin D-deficient individuals PTH levels ranged from 19.5 to $86.4 \mathrm{pg} / \mathrm{mL}$, whereas among vitamin D-replete individuals PTH levels ranged from 17.9 to $58.6 \mathrm{pg} / \mathrm{mL}$. Analysis with Kendall's Tau showed a significant inverse relationship between PTH and 25(OH)D (Kendall coefficient -0.225 , $P<0.001$; Pearson's $R=-0.302, P<0.0001$; Fig. 2). Kruskal-Wallis analysis revealed a statistically significant difference in serum PTH level between the three vitamin D clinical categories $(25(\mathrm{OH}) \mathrm{D} \leq 20,>20$ to $<30$, and $\geq 30 \mathrm{ng} / \mathrm{mL}$ ). A further analysis of multiple comparisons based on pairwise rankings revealed significant differences between each pair $(25(\mathrm{OH}) \mathrm{D} \geq 30$ vs $>20$ to $<30 \mathrm{ng} / \mathrm{mL}$, $P=0.008 ; \geq 30$ vs $\leq 20 \mathrm{ng} / \mathrm{mL}, P<0.0001 ;$ and $>20$ to $<30$ vs $\leq 20 \mathrm{ng} / \mathrm{mL}, P=0.001$ ).

Median PTH concentration was significantly higher in black/African American individuals $(40.4 \mathrm{pg} / \mathrm{mL})$ than in white individuals $(34.7 \mathrm{pg} / \mathrm{mL} ; P=0.001$; Fig. 3 ), with the greatest between-race difference observed among individuals in the $\leq 20 \mathrm{ng} / \mathrm{mL} 25(\mathrm{OH}) \mathrm{D}$ category. Fewer black/ African American individuals were in the $>20$ to $<30$ and $\geq 30 \mathrm{ng} / \mathrm{mL}$ vitamin D categories compared with white individuals $(25.9 \%$ vs $74.1 \%$ and $12.1 \%$ vs $85.8 \%$, respectively; Fig. 3), and accordingly, median 25(OH)D levels were

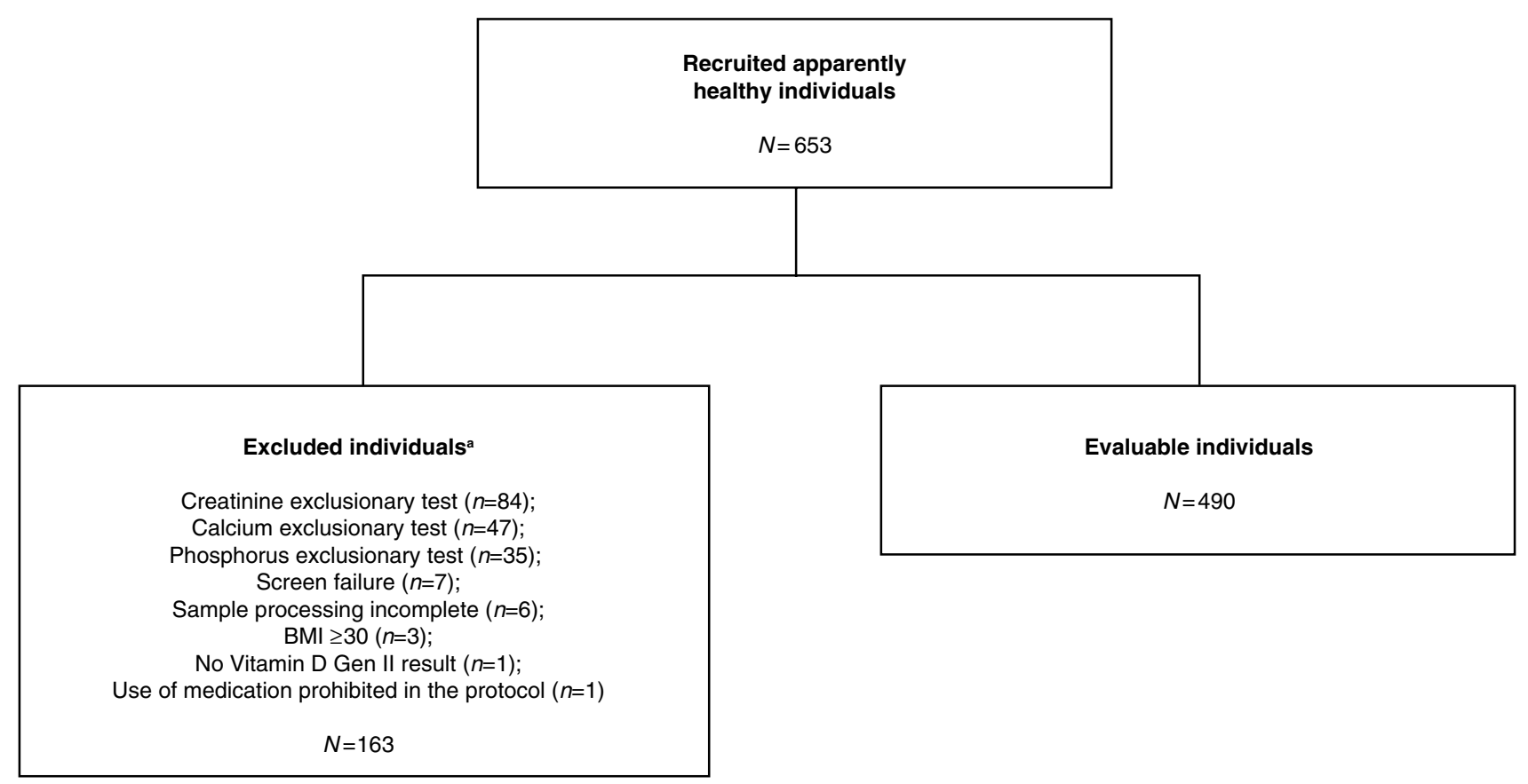

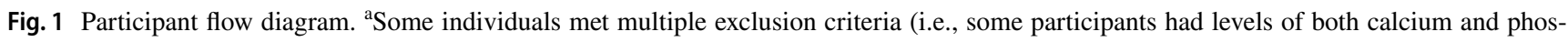
phorus that exceeded requirements). BMI body mass index 


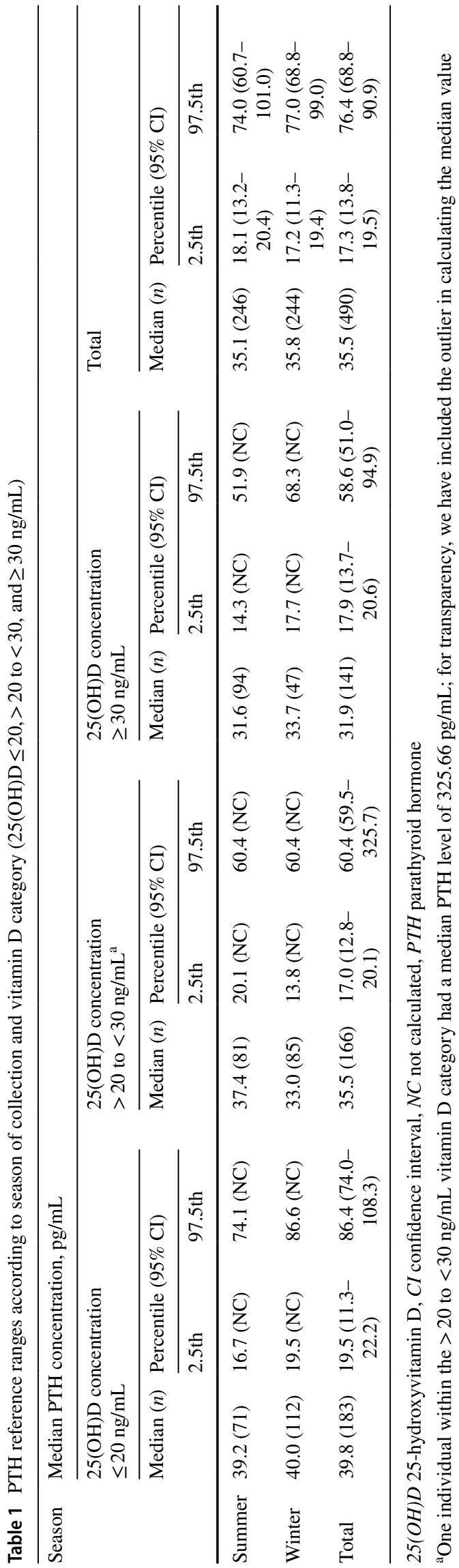

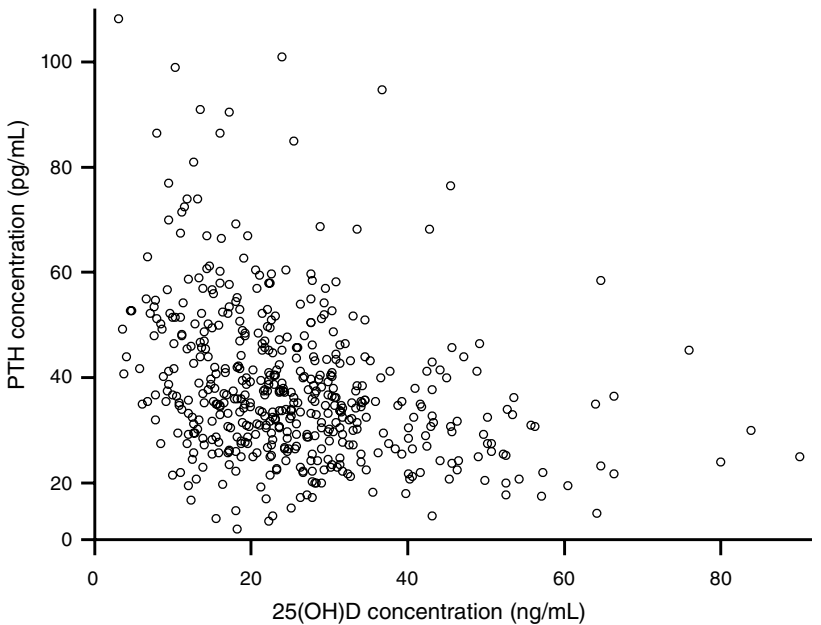

Fig. 2 Inverse relationship between PTH and 25(OH)D in a USA reference population. $25(\mathrm{OH}) \mathrm{D}$ 25-hydroxyvitamin $\mathrm{D}, \mathrm{PTH}$ parathyroid hormone

highest in white individuals $(26.7 \mathrm{ng} / \mathrm{mL})$ compared with black/African American $(17.2 \mathrm{ng} / \mathrm{mL} ; P=0.0001)$ and other individuals $(15.9 \mathrm{ng} / \mathrm{mL} ; P=0.0017)$.

\section{Categorical analysis}

Kruskal-Wallis analyses showed that any additional effects of race or season as covariates were relatively small or absent. No significant differences were found between black/ African American versus other or white versus other. No statistically significant relationship was found between PTH level and sample collection season.

Median serum PTH concentrations (2.5th-97.5th percentile) were significantly different between Indianapolis versus St Paul $(P=0.01)$ and Indianapolis versus Daytona Beach $(P=0.0007)$ : in the overall population, values were $33.3 \mathrm{pg} / \mathrm{mL}(17.7-69.2 \mathrm{pg} / \mathrm{mL})$ for Daytona Beach, $37.6 \mathrm{pg} /$ $\mathrm{mL}(16.7-86.4 \mathrm{pg} / \mathrm{mL})$ for Indianapolis, and $35.2 \mathrm{pg} / \mathrm{mL}$ (17.0-66.6 pg/mL) for St Paul. No significant difference was observed between St Paul and Daytona Beach (North vs South USA).

\section{Linear regression modeling}

Linear modeling confirmed the highly significant relationship between PTH and vitamin D status (according to 25(OH)D; $P<0.0001$; Table 2). Using the model $\log (\mathrm{PTH})=25(\mathrm{OH}) \mathrm{D}+$ race $+25(\mathrm{OH}) \mathrm{D} \times$ race, significant effects on serum PTH were observed for the variables $25(\mathrm{OH}) \mathrm{D}$ status $(P=0.005)$, race $(P=0.01)$, and the interaction between race and $25(\mathrm{OH}) \mathrm{D}$ status $(P=0.03)$. The variable race did not have a significant effect on serum PTH concentration when the interaction variable $25(\mathrm{OH}) \mathrm{D} \times$ race 
Fig. 3 PTH levels by vitamin D category $(25(\mathrm{OH}) \mathrm{D} \leq 20$, $>20$ to $<30$, and $\geq 30 \mathrm{ng} / \mathrm{mL}$ ) for each race. ${ }^{\text {aS }}$ ample cohorts for Asian, other, and more than one race were combined into one category [presented here as 'other' $(n=16)$ ] due to small sample sizes for each $25(\mathrm{OH}) \mathrm{D}$ category. 25(OH)D 25-hydroxyvitamin $\mathrm{D}, P T H$ parathyroid hormone

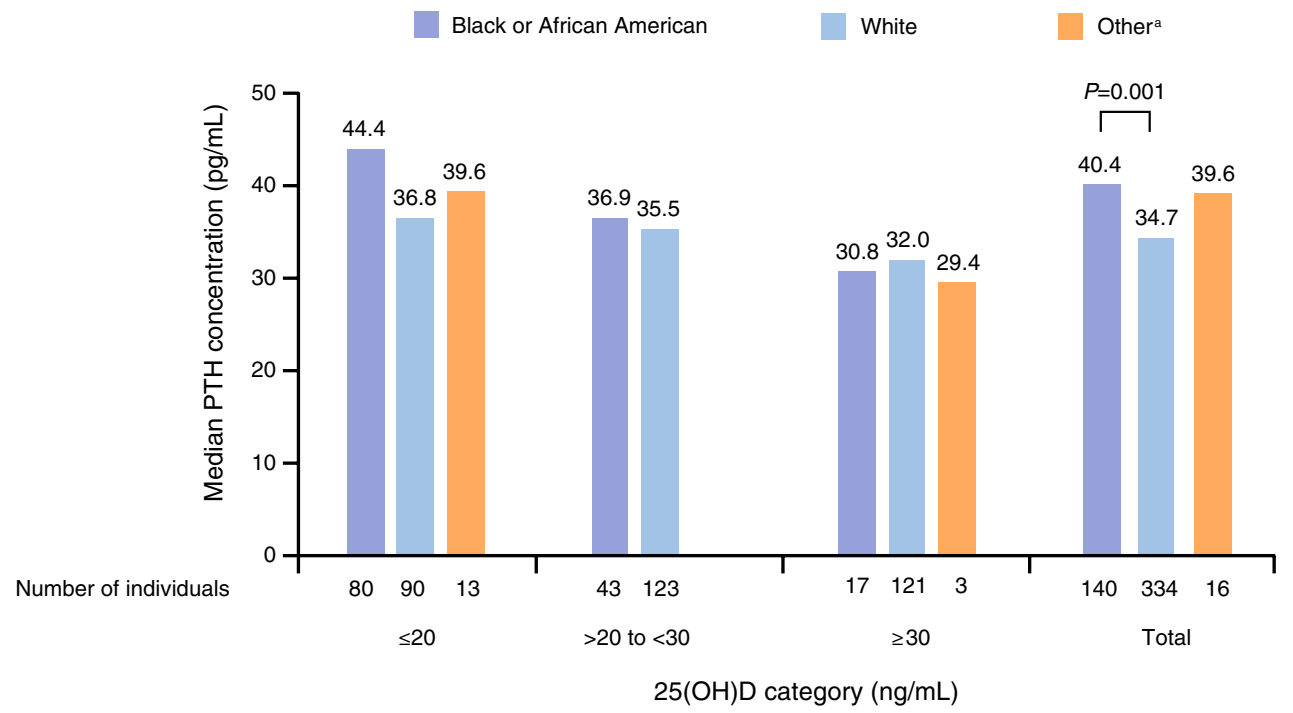

\begin{tabular}{|c|c|c|c|c|c|}
\hline Parameter & $\begin{array}{l}\text { Degrees of } \\
\text { freedom }\end{array}$ & Sum-of-squares & Mean squares & $F$ value & $P$ value \\
\hline \multicolumn{6}{|c|}{$\log \mathrm{PTH}=25(\mathrm{OH}) \mathrm{D}+$ race $+25(\mathrm{OH}) \mathrm{D} \times$ race } \\
\hline $25(\mathrm{OH}) \mathrm{D}$ & 1 & 0.98 & 0.98 & 7.81 & 0.0054 \\
\hline Race & 2 & 1.08 & 0.54 & 4.30 & 0.0142 \\
\hline $25(\mathrm{OH}) \mathrm{D} \times$ race & 2 & 0.86 & 0.43 & 4.43 & 0.0331 \\
\hline \multicolumn{6}{|c|}{$\log \mathrm{PTH}=25(\mathrm{OH}) \mathrm{D}+$ race } \\
\hline $25(\mathrm{OH}) \mathrm{D}$ & 1 & 4.61 & 4.61 & 36.4 & $<0.0001$ \\
\hline Race & 2 & 0.44 & 0.22 & 1.73 & 0.179 \\
\hline \multicolumn{6}{|c|}{$\log \mathrm{PTH}=25(\mathrm{OH}) \mathrm{D}+$ site $+25(\mathrm{OH}) \mathrm{D} \times$ site } \\
\hline $25(\mathrm{OH}) \mathrm{D}$ & 1 & 6.23 & 6.23 & 49.5 & $<0.0001$ \\
\hline Site & 2 & 1.13 & 0.56 & 4.48 & 0.0118 \\
\hline $25(\mathrm{OH}) \mathrm{D} \times$ site & 2 & 0.04 & 0.02 & 0.15 & 0.859 \\
\hline \multicolumn{6}{|c|}{$\log \mathrm{PTH}=25(\mathrm{OH}) \mathrm{D}+$ site } \\
\hline $25(\mathrm{OH}) \mathrm{D}$ & 1 & 6.23 & 6.23 & 49.7 & $<0.0001$ \\
\hline Site & 2 & 1.13 & 0.56 & 4.50 & 0.0116 \\
\hline
\end{tabular}

25(OH)D 25-hydroxyvitamin D, $P T H$ parathyroid hormone
Table 2 Regression modeling to estimate the effect of $25(\mathrm{OH}) \mathrm{D}$, race, and sample collection site on PTH concentration

\section{Discussion}

was not included in the model, i.e., $\log (\mathrm{PTH})=25(\mathrm{OH})$ $\mathrm{D}+\operatorname{race}(P=0.18)$. A further analysis was done to evaluate $25(\mathrm{OH}) \mathrm{D}$ status by race, and it showed that serum $25(\mathrm{OH}) \mathrm{D}$ concentrations were significantly higher in white individuals compared with black/African American $(P<0.0001)$ and other $(P=0.002)$ individuals.

To assess the effect of collection site on PTH level, the model $\log (\mathrm{PTH})=25(\mathrm{OH}) \mathrm{D}+$ site $+25(\mathrm{OH}) \mathrm{D} \times$ site was used. The variables $25(\mathrm{OH}) \mathrm{D}(P<0.0001)$ and site $(P=0.01)$ both had significant effects on serum PTH level; however, the interaction between site and $25(\mathrm{OH}) \mathrm{D}$ did not $(P=0.86)$. Similar results were observed using the model $\log (\mathrm{PTH})=25(\mathrm{OH}) \mathrm{D}+$ site $(25(\mathrm{OH}) \mathrm{D}, P<0.0001$; site, $P=0.01)$.
We identified an inverse relationship between PTH and vitamin D levels in serum samples from apparently healthy individuals collected over two seasons across three geographically diverse locations in the USA. The URL for PTH was lower when determined in vitamin D-replete individuals compared with vitamin D-deficient and insufficient individuals. Using the Elecsys ${ }^{\circledR}$ PTH immunoassay, we determined a PTH reference range of $17.9-58.6 \mathrm{pg} / \mathrm{mL}$ in vitamin D-replete individuals. Previous studies in vitamin D-replete Caucasian individuals have reported URLs of $64 \mathrm{pg} / \mathrm{mL}$ $\left(\right.$ Elecsys $^{\circledR}$ ) and $45.3 \mathrm{pg} / \mathrm{mL}\left(\right.$ Elecsys $\left.^{\circledR}\right)$ [6, 20]. Differences in population demographics/characteristics (e.g., age, race, 
BMI) and preanalytical considerations (e.g., time of sample collection, fasting state of volunteer, EDTA plasma/serum), as well as site-specific factors, may contribute to betweenstudy differences in URL [3, 4, 9, 21]. In vitamin D-deficient subjects, PTH values ranged from 19.5 to $86.4 \mathrm{pg} / \mathrm{mL}$, demonstrating a $47 \%$ increase in the URL.

Upper reference limits for PTH in the $>20$ to $<30 \mathrm{ng} / \mathrm{mL}$ and $\geq 30 \mathrm{ng} / \mathrm{mL}$ vitamin D categories were similar (60.4 and $58.6 \mathrm{pg} / \mathrm{mL}$, respectively, compared with $86.4 \mathrm{pg} / \mathrm{mL}$ for vitamin $\mathrm{D} \leq 20 \mathrm{ng} / \mathrm{mL}$ ). This suggests that clinically important elevations in PTH tend to be observed in vitamin D deficiency rather than vitamin D insufficiency. Consistent with our findings, large increases in the upper reference limit for PTH were found previously for vitamin D levels $\leq 12 \mathrm{ng} /$ $\mathrm{mL}$ in a cohort of women aged $17-84$ years, where $25(\mathrm{OH})$ $\mathrm{D}$ levels were analyzed by isotype dilution liquid chromatography-tandem mass spectrometry, and PTH levels were evaluated using the Elecsys ${ }^{\circledR}$ PTH assay [22]. The results do not seem to be population specific, since race, season, and latitude do not add to the ability to predict PTH over that of 25(OH)D alone.

The dominant covariate associated with PTH was vitamin D level. A relationship between race and PTH was also observed, but it was complex. Overall, the addition of race to a statistical model predicting PTH using vitamin D levels did not improve the model, indicating that separate reference ranges by race may not be required. However, previous studies suggest that African American individuals manifest several differences in calcium-related pathways compared with white individuals [23]. In the present analyses, black/ African Americans had higher levels of PTH and lower levels of vitamin D compared with Caucasian individuals, with the greatest difference in PTH observed among vitamin D-deficient individuals. In addition, a statistically significant interaction was found between race and vitamin $\mathrm{D}$ in predicting PTH levels, indicating that effects of vitamin D on PTH differ between races. These findings are consistent with recent data showing similar findings, and suggest that vitamin D bioavailability or metabolism may be different in African Americans compared with Caucasians [23, 24]. Season and latitude were generally not predictive of PTH levels, but other differences between collection sites were identified [25, 26].

Limitations of the study include a gender imbalance (protocol-specified: $50 \pm 5 \%$ not achieved), and predominance of individuals aged $<60$ years; so results may not be generalizable to older individuals in whom elevated PTH concentrations have been observed [27]. Ethnic differences in PTH levels have previously been reported for Asian individuals; our results may, therefore, not be applicable to regions with larger Asian populations, as most individuals enrolled were Caucasian $(68.2 \%)$ or black/African American (28.6\%) [28]. However, the study population is reflective of USA sample collection sites and consistent with an earlier FDA request to include 30\% black/African American individuals for determination of expected values for $25(\mathrm{OH}) \mathrm{D}$. Previous studies have shown good analytical performance for both the Elecsys ${ }^{\circledR}$ Vitamin D total II and PTH assays; recently, Batista et al. [29] found good agreement between the Elecsys ${ }^{\circledR}$ Vitamin D total II assay and LC-MS/MS (90.8\%), with mean imprecision and inaccuracy below $10 \%$ and 5\%, respectively, as recommended by the Vitamin D External Quality Assessment Scheme (DEQAS) [30]. Furthermore, the Elecsys ${ }^{\circledR}$ Vitamin D total II assay has received CDC certification [31], and demonstrates excellent comparability with CDC verification samples that have concentrations assigned by the CDC vitamin D reference laboratory using ID-LC-MS/MS (Deming regression: $y=0.954 x-0.707 ; r=0.982$ ) [32]. The assay also shows excellent comparability with DEQAS samples that have assigned target values from the US National Institute for Standards and Technology [NIST; sample numbers 476-490; mean recovery $100 \%$ (84-110\%); mean relative bias $-0.4 \%$ ] [32]. For the Elecsys ${ }^{\circledR}$ PTH assay, Hermsen et al. [33] found coefficients of variation of $\leq 6.6 \%$ and $\leq 15.6 \%$ for within-run and between-day precision, respectively.

Key strengths of the study include conduct of analyses in accordance with CLSI guidelines and classification of vitamin D-replete individuals based on a $25(\mathrm{OH}) \mathrm{D}$ serum concentration of $\geq 30 \mathrm{ng} / \mathrm{mL}$, as opposed to $>20 \mathrm{ng} / \mathrm{mL}$ in earlier studies; the higher threshold may be more relevant to patient populations than to the general population $[9$, 17].

This study provides new reference ranges for the Elecsys ${ }^{\circledR}$ PTH assay, determined in serum from a large population of apparently healthy individuals, stratified according to three categories of $25(\mathrm{OH}) \mathrm{D}$ concentration. The availability of robust reference ranges accounting for $25(\mathrm{OH}) \mathrm{D}$ status is likely to facilitate clinical decision-making.

Acknowledgements Third-party medical writing assistance, under the direction of the authors, was provided by David Evans, $\mathrm{PhD}$, and Chloe Fletcher, MSc (Gardiner-Caldwell Communications, Macclesfield, UK) and funded by Roche Diagnostics International Ltd (Rotkreuz, Switzerland). COBAS, COBAS E and ELECSYS are trademarks of Roche.

Funding This study was funded by Roche Diagnostics International Ltd (Rotkreuz, Switzerland).

\section{Compliance with ethical standards}

Conflict of interest Richard Ostlund has received research support from Roche Diagnostics and Regeneron. Gabriella Bobba, Ge Guo, and Ann Stankiewicz are employees of Roche Diagnostics. Naga Yalla has no conflicts of interest to disclose. 
Ethical approval All procedures performed in studies involving human participants were in accordance with the ethical standards of the institutional and/or national research committee and with the 1964 Helsinki declaration and its later amendments or comparable ethical standards. Institutional review board approval was obtained from all participating sites prior to study initiation.

Informed consent Informed consent was obtained from all individual participants included in the study.

Open Access This article is distributed under the terms of the Creative Commons Attribution 4.0 International License (http://creativeco mmons.org/licenses/by/4.0/), which permits unrestricted use, distribution, and reproduction in any medium, provided you give appropriate credit to the original author(s) and the source, provide a link to the Creative Commons license, and indicate if changes were made.

\section{References}

1. Metzger M, Houillier P, Gauci C et al (2013) Relation between circulating levels of $25(\mathrm{OH})$ vitamin $\mathrm{D}$ and parathyroid hormone in chronic kidney disease: quest for a threshold. J Clin Endocrinol Metab 98:2922-2928

2. Khundmiri SJ, Murray RD, Lederer E (2016) PTH and vitamin D. Compr Physiol 6:561-601

3. Kidney Disease: Improving Global Outcomes (KDIGO) CKDMBD Work Group (2009) KDIGO clinical practice guideline for the diagnosis, evaluation, prevention, and treatment of chronic kidney disease - mineral and bone disorder (CKD-MBD). Kidney Int Suppl 113:S1-S130

4. National Kidney Foundation (2003) K/DOQI clinical practice guidelines for bone metabolism and disease in chronic kidney disease. Am J Kidney Dis 42(4 Suppl 3):S1-S201

5. Lee JH, Choi J-H, Kweon OJ, Park AJ (2015) Discrepancy between vitamin $\mathrm{D}$ total immunoassays due to various crossreactivities. J Bone Metab 22:107-112

6. Cavalier E, Delanaye P, Vranken L et al (2012) Interpretation of serum PTH concentrations with different kits in dialysis patients according to the KDIGO guidelines: importance of the reference (normal) values. Nephrol Dial Transplant 27:1950-1956

7. Forrest KY, Stuhldreher WL (2011) Prevalence and correlates of vitamin D deficiency in US adults. Nutr Res 31:48-54

8. Eastell R, Brandi ML, Costa AG, D'Amour P, Shoback DM, Thakker RV (2014) Diagnosis of asymptomatic primary hyperparathyroidism: proceedings of the fourth international workshop. J Clin Endocrinol Metab 99:3570-3579

9. Souberbielle JC, Brazier F, Piketty ML, Cormier C, Minisola S, Cavalier E (2017) How the reference values for serum parathyroid hormone concentration are (or should be) established? J Endocrinol Investig 40:241-256

10. Souberbielle JC, Lawson-Body E, Hammadi B, Sarfati E, Kahan A, Cormier C (2003) The use in clinical practice of parathyroid hormone normative values established in vitamin D-sufficient subjects. J Clin Endocrinol Metab 88:3501-3504

11. Cantor T, Yang Z, Caraiani N, Ilamathi E (2006) Lack of comparability of intact parathyroid hormone measurements among commercial assays for end-stage renal disease patients: implication for treatment decisions. Clin Chem 52:1771-1776

12. Roche Diagnostics GmbH (2018) Elecsys vitamin D total II package insert. Roche, Mannheim

13. Roche Diagnostics GmbH (2014) Elecsys PTH package insert. Roche, Mannheim
14. Sempos CT, Vesper HW, Phinney KW et al (2012) The vitamin D standardisation program (VDSP). Vitamin D status as an international issue: national surveys and the problem of standardisation. Scand J Clin Lab Investig 72(Suppl 243):32-40

15. Thienpont LM, Stepman HCM, Vesper HW (2012) Standardisation of measurements of 25-hydroxyvitamin D3 and D2. Scand J Clin Lab Investig 72(Suppl 243):41-49

16. Phinney KW (2008) Development of a standard reference material for vitamin D in serum. Am J Clin Nutr 88:511-512

17. Clinical and Laboratory Standards Institute (CLSI) (2010) Defining, establishing, and verifying reference intervals in the clinical laboratory; approved guideline, 3rd edn. Document EP28-A3c. CLSI, Wayne

18. Watts NB, Bilezikian JP, Camacho PM et al (2010) American Association of Clinical Endocrinologists Medical Guidelines for Clinical Practice for the diagnosis and treatment of postmenopausal osteoporosis: executive summary of recommendations. Endocr Pract 16:1016-1019

19. Holick MF, Binkley NC, Bischoff-Ferrari HA et al (2011) Evaluation, treatment, and prevention of vitamin D deficiency: an Endocrine Society clinical practice guideline. J Clin Endocrinol Metab 96:1911-1930

20. Touvier M, Deschasaux M, Montourcy M et al (2014) Interpretation of plasma PTH concentrations according to 25OHD status, gender, age, weight status, and calcium intake: importance of the reference values. J Clin Endocrinol Metab 99:1196-1203

21. Carter GD, Carter R, Jones J, Berry J (2004) How accurate are assays for 25-hydroxyvitamin D? Data from the international vitamin D external quality assessment scheme. Clin Chem 50:2195-2197

22. Rejnmark L, Vestergaard P, Heickendorff L, Mosekilde L (2011) Determinants of plasma PTH and their implication for defining a reference interval. Clin Endocrinol (Oxf) 74:37-43

23. Gutiérrez OM, Farwell WR, Kermah D, Taylor EN (2011) Racial differences in the relationship between vitamin $\mathrm{D}$, bone mineral density, and parathyroid hormone in the National Health and Nutrition Examination Survey. Osteoporos Int 22:1745-1753

24. Aloia JF, Feuerman M, Yeh JK (2006) Reference range for serum parathyroid hormone. Endocr Pract 12:137-144

25. Lamberg-Allardt CJ, Outila TA, Karkkainen MU, Rita HJ, Valsta LM (2001) Vitamin D deficiency and bone health in healthy adults in Finland: could this be a concern in other parts of Europe? J Bone Miner Res 16:2066-2073

26. United Health Foundation (2007) America's health rankings: annual report 2017. https://www.americashealthrankings.org/ learn/reports/2017-annual-report. Accessed 9 Nov 2018

27. Souberbielle JC, Massart C, Brailly-Tabard S et al (2016) Serum PTH reference values established by an automated third-generation assay in vitamin D-replete subjects with normal renal function: consequences of diagnosing primary hyperparathyroidism and the classification of dialysis patients. Eur J Endocrinol 174:315-323

28. Yan L, Schoenmakers I, Zhou B et al (2009) Ethnic differences in parathyroid hormone secretion and mineral metabolism in response to oral phosphate administration. Bone 45:238-245

29. Batista MC, Menegat FD, Ferreira CES, Faulhaber ACL, Campos DALS, Mangueira CLP (2018) Analytical and clinical validation of the new Roche Elecsys Vitamin D Total II assay. Clin Chem Lab Med 56:e298-e301

30. Carter GD, Berry J, Durazo-Arvizu R et al (2018) Hydroxyvitamin D assays: an historical perspective from DEQAS. J Steroid Biochem Mol Biol 177:30-35

31. Centers for Disease Control and Prevention. CDC vitamin D standardisation-certification program (CDC VDSCP): certified total 25-hydroxyvitamin D procedures. https://www.cdc.gov/labst 
andards/pdf/hs/CDC_Certified_Vitamin_D_Procedures-508.pdf. Accessed 5 Sep 2018

32. Broders O, Engel A, Gerg M, Josel H-P, Vogl C (2017) Locking up 24,25-dihydroxyvitamin D: a new assay for 25-hydroxyvitamin D with improved specificity. Clin Chem Lab Med 55(Suppl):S309

33. Hermsen D, Franzson L, Hoffmann JP et al (2002) Multicenter evaluation of a new immunoassay for intact PTH measurement on the Elecsys System 2010 and 1010. Clin Lab 48:131-141
Publisher's Note Springer Nature remains neutral with regard to jurisdictional claims in published maps and institutional affiliations. 